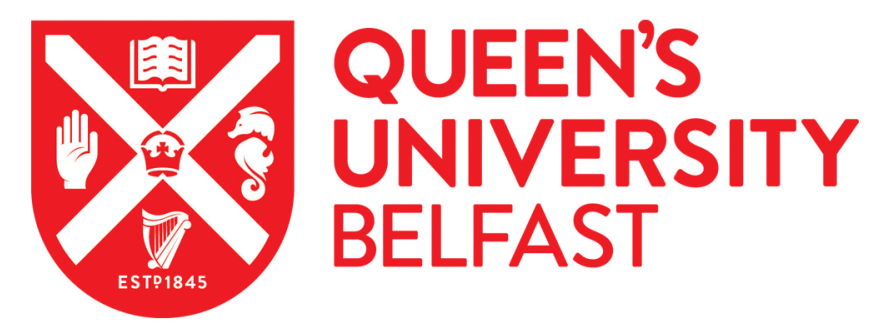

\title{
Trends in Approval Times for Genetically Engineered Crops in the United States and the European Union
}

Smart, R. D., Blum, M., \& Wesseler, J. (2016). Trends in Approval Times for Genetically Engineered Crops in the United States and the European Union. Journal of Agricultural Economics. https://doi.org/10.1111/14779552.12171

Published in:

Journal of Agricultural Economics

Document Version:

Peer reviewed version

Queen's University Belfast - Research Portal:

Link to publication record in Queen's University Belfast Research Portal

Publisher rights

(C) 2016 The Agricultural Economics Society

This is the peer reviewed version of the following article: Smart, R. D., Blum, M. and Wesseler, J. (2016), Trends in Approval Times for Genetically Engineered Crops in the United States and the European Union. Journal of Agricultural Economics, which has been published in final form at http://onlinelibrary.wiley.com/wol1/doi/10.1111/1477-9552.12171/abstract. This article may be used for non-commercial purposes in accordance with Wiley Terms and Conditions for Self-Archiving.

\section{General rights}

Copyright for the publications made accessible via the Queen's University Belfast Research Portal is retained by the author(s) and / or other copyright owners and it is a condition of accessing these publications that users recognise and abide by the legal requirements associated with these rights.

\section{Take down policy}

The Research Portal is Queen's institutional repository that provides access to Queen's research output. Every effort has been made to ensure that content in the Research Portal does not infringe any person's rights, or applicable UK laws. If you discover content in the Research Portal that you believe breaches copyright or violates any law, please contact openaccess@qub.ac.uk. 
*** FINAL VERSION ***

Title: Trends in Genetically Engineered Crops' Approval Times in the United States and the European Union

\author{
Richard D. Smart, Matthias Blum and Justus Wesseler ${ }^{1}$
}

\begin{abstract}
Genetically engineered (GE) crops are subject to regulatory oversight to ensure their safety for humans and the environment. Their approval in the European Union (EU) starts with an application in a given Member State followed by a scientific risk assessment, and ends with a political decision-making step (risk management). In the United States (US) approval begins with a scientific (field trial) step and ends with a 'bureaucratic' decision-making step. We investigate trends for the time taken for these steps and the overall time taken for approving GE crops in the US and the EU. Our results show that from 1996-2015 the overall time trend for approval in the EU decreased and then flattened off, with an overall mean completion-time of 1,763 days. In the US in 1998 there was a break in the trend of the overall approval time. Initially, from 1988 until 1997 the trend decreased with a mean approval time of 1,321 days; from 1998-2015, the trend almost stagnated with a mean approval time of 2,467 days.
\end{abstract}

Keywords: GE; genetically modified organism (GMO); transgenic; US; EU; regulatory oversight; authorization.

JEL Classifications: O32, O38, O57, Q16 Food and Life Sciences Weihenstephan, Technische Universität München, Germany. Matthias Blum is at the Queen's University Management School, Queen's University Belfast, United Kingdom. Justus Wesseler is at Wageningen University, The Netherlands. Justus Wesseler acknowledges support for funding from the European Union's Seventh Framework Programme (FP7/2007-2013) under grant agreement no. KBBE-2011-5-289157. 


\section{Introduction}

Genetically engineered (GE) crops are innovations that need to clear all regulatory hurdles of a given jurisdiction before they can be commercialized - a time-consuming process. In theory, these regulations ("governmental oversight") are used by governments to ensure the safety of new biotech products for humans and the environment (Lynch and Vogel, 2001).

Complying with regulations is costly (Davison, 2010; Miller and Bradford, 2010) (the mean total cost of introducing a new GE crop for the period 2008-2012 was US\$136 M of which US\$ 35.01 $\mathrm{M}(25.8 \%)$ were for meeting regulatory requirements (regulatory science (US\$ $17.9 \mathrm{M})$; registration and regulatory affairs (US\$17.2 M)) (Phillips McDougall, 2011). Kalaitzandonakes et al. (2007) identified compliance costs for insect resistant and herbicide tolerant maize of US\$ 7.1-15.4 M and US\$ 6.2-14.5 M, respectively, often affordable only by large private organizations (Bradford et al., 2005; Giddings et al., 2013).

Numerous investigations have shown a spectrum of benefits (pecuniary, non-pecuniary, and environmental) of adopting first generation GE crops (e.g. Benbrook, 2012; Bennett et al., 2013; Mannion and Morse, 2013; Brookes and Barfoot, 2014). A meta-analysis by Klümper and Qaim (2014) shows that "the average agronomic and economic benefits of GM [(genetically modified)] crops are large and significant". Second-generation GE crops such as micronutrient enriched food crops are expected to improve the health, life-expectancy, and welfare of especially impoverished consumers (Wesseler and Zilberman, 2014; De Steur et al., 2015).

The international regulatory framework is fragmented (Vigani and Olper, 2015) and "highly heterogeneous" because of differences, inter alia, in standards for genetically modified organisms, endogenous policy and the market for information, which affects welfare distribution (Vigani and Olper, 2013). Delays in authorizing GE crops postpone their benefits and cause economic losses in foregone profits. Losses are further exaggerated by asynchronous approval processes, which cause market disruptions (Vigani et al., 2012), and lead to strained trading relations (Henseler et al., 2013; de Faria and Wieck, 2015; De Steur et al., 2015) that in some cases have escalated to formal international disputes (Punt and Wesseler, 2015). Potential environmental and human health benefits are also delayed (Wesseler et al., 2011).

The period for applications successfully moving through the GE crop regulatory pipeline, extended by unforeseen regulatory delays, and the asynchrony in approval between trading partners, is of economic importance for participants in a new GE crop's value chain (Stein and RodríguezCerezo, 2009; Nowicki et al., 2010). In their study on the cost of compliance in the Philippines, Bayer et al. (2010) note that a country's regulatory costs appear to fall over time as experience is gained, while regulatory costs are lower for products that have already been approved elsewhere 
(and by implication, regulatory time is shorter). These authors conclude that: "the largest potential constraint to commercialization ... is regulatory delay". Temporal aspects of regulations have socio-political implications for their regulators and policy evolution due to the opposing pressures exerted on this 'ecosystem' by the antagonists and protagonists of this type of green biotechnology who lobby for more lenient and stricter regulations, respectively. Antagonists have contributed to regulatory delays through legal recourse (DeFrancesco, 2013), state action (e.g. the de facto moratorium in the European Union (EU) lasting from 1998-2004 (Cararu, 2009; Davison, 2010)), and social protest activities such as destroying field trials (Bonneuil et al., 2008; Morris and Spillane, 2010).

We investigate the time taken for GE crops to pass through the regulatory pipelines of the United States (US) and the EU_- "first movers" worldwide in implementing regulations for GE crops (Vigani and Olper, 2015) and important trading partners in these commodities. We identify the trends that have developed since the first GE crop was approved in the US, and provide an improved understanding of the time taken for each regulatory step in these jurisdictions. We deliberately avoid any statistical comparison of the two region's total approval time (see 2.4 below). Because the 'economic clock' theoretically never stops, we ignore any technical stoppages that a 'regulatory clock' might accommodate (e.g. regulators' requests for additional information).

We add to current knowledge (The European Association for Bioindustries, 2011) by giving an updated analysis of the time taken for GE crops to be approved by analyzing: (1) each step in the regulatory 'path' for its contribution to the overall regulatory process, and (2) crop characteristics' impact on regulatory time.

In the next section we describe the regulatory processes in the US and EU to show their differences and similarities and to set the scene for our research method. In the Analysis section we describe the data we used and the statistical analyses done. Thereafter we discuss our results and end by giving our conclusions.

\section{The Regulation of GE Crops in the US and the EU}

\subsection{Introduction}

Although a new GE crop typically follows a seven-stage development process (see Phillips McDougall, 2012), regulatory oversight in the US begins with stage six involving the scientific evaluation of a new crop's safety and ends in a 'bureaucratic' decision-making step. In the EU however, there is an additional political decision-making step (Lynch and Vogel, 2001; Davison, 2010). 


\section{2. $U S$}

The US Department of Agriculture (USDA) takes the lead role for approving GE crops, and is supported by the Environmental Protection Agency and the Food and Drug Administration (Office of Science and Technology Policy, 1986). We consider the start of the regulatory process (i.e. when the 'economic clock' starts) to be when a developer first seeks permission at the USDA's Animal and Plant Health Inspection Service (APHIS) for conducting field trials on a regulated article - the name for GE crops not yet approved - irrespective of when its first field trial actually starts. This 'scientific' (field trial) step ends when the developer submits its petition dossier to the APHIS petitioning for non-regulated status, which in turn marks the beginning of the 'bureaucratic' step during which the scientific evidence of its safety is assessed. This step ends when the regulated article is assigned non-regulated status. The petitioner is then legally permitted to market the GE crop. Details of this process up to the end of February 2012 are shown in Figure S1 in the on-line appendix. From March 2012 the process was changed to facilitate earlier public involvement, and the way in which public comments are solicited and used (Figure S2, on-line) (USDA APHIS, 2012).

\section{3. $E U$}

The EU's approval process is legally guided by the precautionary principle, and commences for the purposes of our study when a developer applies to its Member State's competent authority for approving a GE crop. Approval is for a specific use, e.g. 'cultivation', and or 'food and or feed', and or 'import and processing', or any combination of these. The Member State passes this application on to the European Food Safety Authority (EFSA) for assessment in terms of the Council Directive 2001/18/EC.

The EFSA is an independent body operating since 2002 for providing the European Community with scientific and technical support for food and feed safety issues, and is mandated to conduct risk assessments_- “... a scientifically based process consisting of four steps: hazard identification, hazard characterisation, exposure assessment and risk characterisation ..." (Council Regulation (EC) No 178/2002). This 'risk assessment' step (similar to the petitioning 'bureaucratic' step in the US) ends when the EFSA issues its opinion. This opinion is passed on to the European Commission (EC) for the final "risk management" ('political' step) phase of regulatory oversight (Council Regulation (EC) No 178/2002; EFSA, 2015).

The EC prepares a draft decision based on the EFSA's opinion, and submits it to a committee comprising representatives of each Member State - the Standing Committee on the Food Chain (SCFCAH) - for a decision that is reached by qualified majority voting under Regulation 
1829/2003 (if submitted under Directive 2001/18, then by the Regulatory Committee) (EC, 2016). If the SCFCAH rejects the draft decision or expresses a 'no opinion', the EC either amends its draft decision and resubmits it to the SCFCAH or submits the original draft decision to the Appeal Committee — a more senior level of Member State representation—for a decision (EC, 2015), also by qualified majority voting. Similarly, approval is declined if the draft decision is rejected, but if a 'no opinion' is expressed, the EC may adopt the decision, i.e. approval will be granted (Figure S3 from Smart et al., 2015, on-line). The 'political' step, and therefore the approval process, stops when the Commission reaches its decision (Davison, 2010). We considered the combined duration of the Member State-application, the 'risk assessment', and the political decision-making steps to be the total duration of the EU's approval process.

Most (97\%) of the applications in the EU have been for 'food and or feed' and or 'industrial purposes'. For these applications, results of field trials done outside of the EU are cited (Council Directive 2001/18/EC). Field trials done in the EU are required for applications for 'cultivation' use only. Due to the low number (two applications for cultivation) of observations in our study, we excluded a 'field trial' step for our EU analysis.

\section{$2.4 \quad$ Synthesis}

It is tempting to make a direct comparison of the approval length between the US and the EU. However, a direct comparison is insensible. The approval system of the US starts with a 'scientific' step characterised by field trials and ends with a 'bureaucratic' step for assessing the applicant's petition, while that of the EU starts when a developer applies to its Member State for approval for one or more specific uses (see 2.3 above), followed by a 'risk assessment' step (similar to the US's 'bureaucratic' step), ending in a political decision-making process. Some of the information generated for approval in the EU relies on information generated for the approval process in the US. Further, applications in the US almost always include field trials as applications include cultivation, while the majority of the applications for approval in the EU are for "import and processing" and not for "cultivation" (Wesseler and Kalaitzandonakes, 2011). Thus, we avoid a statistical comparison of their total approval time as it would be theoretically flawed. Rather, we focus on trends exhibited in each system separately.

\section{Analysis}

We investigate the completion-time for the steps involved in the approval of GE crops in the US and the EU, and assume that the arithmetic sum of these steps is the total duration of each jurisdiction's approval process. Because we are dealing with an 'economic' rather than a 
'regulatory' clock, we do not account for stoppages. We sourced our data for all newly approved GE crops (i.e. excluding renewals) until December 2015 (the end of our study period) from internetbased databases and journals.

Our first observation in the US is December 12, 1988, the application date for permission for the first field trial for the GE tomato: Flavr Savr. Although approvals are ongoing, our final observation is December 8, 2015, the deregulation date for the GE maize event MON 87403. The corresponding dates for the EU are August 5, 1996 (submission date to Sweden's competent authority for the GE potato event EH92-527-1) and December 4, 2015 (Commission decision for the maize events MON 87427 and NK603 x T25), respectively.

For the US, we investigate all GE crops listed on the USDA's APHIS Biotechnology Regulatory Services (BRS) website that have been granted non-regulated status, and those that are awaiting the APHIS's decision (USDA, 2016a). We found the date for the start of the 'scientific' step by cross-referencing the permit number of a GE plant's earliest field trial (published in its petition dossier) with the BRS's online permit information database (USDA, 2016b), which also contains the other dates we use. We use each regulated article's petition number for finding the dates when its dossier (petition document) was submitted to the APHIS - marking the end of the 'scientific' step and the start of the 'bureaucratic' step - and when non-regulated status was awarded: this signaling the conclusion of the 'bureaucratic' decision-making step, and the entire regulatory process.

The non-regulated status for two glyphosate-tolerant GE crops (alfalfa (events J101 and $\mathrm{J} 163$ ) and sugar beet (event H7-1)) was temporarily suspended due to legal action resulting in their developers having to submit an environmental impact statement; these delays were irrelevant to our empirical analysis as they occurred after their original approvals (USDA APHIS, 2010; 2011), and therefore were excluded. As most of the plants in our dataset are annuals, we excluded the field trial data for perennial crops, but included the time taken for their petitions to be reviewed in our analysis of the 'bureaucratic' step. There are no field trial data available for two annuals (flax (CDC Triffid) and soybean (BPS-CV127-9)), whose trials were done outside of the US.

For the EU, we investigate all GE crops listed on the GMO Compass website's database (GMO Compass, 2016) classified as having a risk assessment report (i.e. the 'scientific-' but not the 'political' step is complete), and a valid authorization (i.e. approved), complemented by notices published in the journal: Agrafacts (Agrafacts, 2015). We cross-reference our list with the EFSA's scientific opinion/s and the Commission's decision in the EFSA Journal and the Official Journal of the European Communities, respectively. We find the following dates for each application: submission for authorization to the EU Member State (start of the Member State-application step); 
EU Member State submission to the EFSA (end of the Member State-application step; start of the scientific 'risk assessment' step); the EFSA's date of adopting the application (end of the 'risk assessment' step; start of 'political' step); and the date when the Commission reached its decision for approving the GE crop (end of 'political' step, and the entire regulatory process). Where the complete date for the start of the Member State-application step is not published, we assume the date to be the fifteenth day of the month during which its application was submitted to the relevant Member State, and we exclude events where no evidence of a date was found from this step's analysis. Tables 1 and 2 show general trends of the regulatory processes, apparently getting longer in the US (the overall trend has a structural break dividing it into an 'early-' and 'late' period, discussed in more detail below) and shorter in the EU.

$<$ INSERT TABLE 1 HERE >>

$<<$ INSERT TABLE 2 HERE $>>$

\subsection{Empirical Analysis}

\subsection{US}

We collected data for 95 observations (applications), all of which except one (awaiting the outcome of the 'bureaucratic' step) are now deregulated. Table 3 presents summary statistics of this dataset. From an initial analysis of our data we identified a structural break in the trend for the time taken to approve GE crops (Table 1, Figure S4, on-line). We used the start date for each application for identifying two groups of applications separated by this break: (1) 'early' (up to and including 1997), and (2) 'late' (1998 onwards), representing $44 \%$ and $56 \%$ of observations, respectively. USbased and foreign developers submitted $75 \%$ and $25 \%$ of the applications, respectively, whereas $69 \%$ and $31 \%$ of the applications were for single- and multiple trait events, respectively. $51 \%$ of the genetic modifications were for herbicide tolerance; $32 \%$ for insect resistance; and $32 \%$ for other genetic modifications such as viral resistance, freeze-tolerance, and quality improvement traits (e.g. reduced browning of apples, and reduced lignin content of alfalfa). The majority (79\%) of GE plants were developed for food production; only $21 \%$ were developed for non-food purposes. GE varieties of maize were the most abundant (32\%); followed by soy bean (18\%); cotton (17\%); tomato, and potato ( $6 \%$ each); the remaining $21 \%$ comprised alfalfa, apple, sugar beet, chicory, creeping bentgrass, eucalyptus, papaya, rice, rose, squash, and tobacco. 


\section{$<<$ INSERT TABLE 3 HERE >>}

We investigated if the structural break mentioned above also holds in a multivariate regression framework. Theoretically, what appears to be a structural break may be a sudden shift in the type of application, for example the characteristic of a GE plant like its lifecycle, i.e., a shift from annual to perennial. Alternatively, the political 'climate' may have caused a shift, thus erroneously indicating a structural break, which was actually the result of unobserved factors. We used a set of ordinary least squares regression models for testing if differences in the regulatory process' time-line could be explained by plant characteristics or an external, independent factor(s) (Figure S4, on-line)

We identified two periods ('early' and 'late') separated in 1998 by a structural break. We captured differences in the time taken for applications completing the 'scientific' step, 'bureaucratic' step, and the overall approval process, by including dichotomous variables. Subsequently, we included additional control variables for netting out effects unrelated to the structural break, such as differences in time taken between applications grouped according to the following parameters: developer's domicile (domestic or foreign developer); use (food or non-food plants); and the number of GE traits that each crop has (single or multiple). If the variable identifying 'early' and 'late' applications reflect a substantial and statistically significant difference after adding controls, our interpretation is that evidence for a structural break exists.

Table S5 (on-line) illustrates the results of our regression models designed to net out effects unrelated to the structural break. Model 1 (baseline model) suggests that submissions made before the structural break took $38 \%$ less time (504 days) $)^{2}$ to complete the scientific step - a robust estimate as it remained almost unaffected by the additional explanatory variables. In model 5, the minimal estimate, 'early' applications took 37\% less time (496 days) than applications submitted during the 'late' period. For the 'scientific' step, neither a developer's domicile nor the genetic trait multiple contributed to differences in regulatory time. Model 5 indicates that there are no substantial differences in regulatory time between potatoes, tomatoes, soy beans, and maize plants; conversely, plants we subsume under 'other crops' took less time for approval compared with maize.

We performed a similar set of analyses for the time taken for a petition passing through the US's 'bureaucratic' step (Table S6, on-line). Petitions from 'early' applications have a substantial time advantage according to model 1 - our baseline model. 'Late' period petitions took 679 days

\footnotetext{
${ }^{2}$ We transformed (natural $\log$ ) the dependent variable as it is not normally distributed.
} 
(144\%) longer to be approved: a robust result for all the models. Petitions from foreign-based developers and for multiple traits took slightly longer than for local developers and single traits, respectively, but some of the corresponding coefficients are statistically insignificant. We detected no difference between herbicide tolerant and insect resistant crops. We performed the same set of tests on the total approval time (Table S7, on-line). The most striking discovery is that one or more events or factors around 1998 triggered a delay in the US's approval process, i.e. developers who applied to the APHIS from 1998 onwards for permission to conduct field trials for the first time on a new GE crop, spent 1,146 days longer (63\%; model 1) in the regulatory pipeline than had permission for their crop's field trials been applied for in 1997 or earlier.

\section{3. $E U$}

We collected data for 65 observations (applications) of which 62 were approved. Table 4 presents these data. The oldest and most recent applications for starting the Member State-application step were submitted in 1996 and 2012, respectively; 32\% and 68\% of the applications were by local and foreign (mostly the US) developers, respectively. $51 \%$ of the applications were for single- and $49 \%$ for multiple-trait GE crops. In $72 \%$ and $51 \%$ of the cases, GE modifications were for herbicide tolerance and insect resistance, respectively, while 16\% were for 'other' traits. Most of the applications were for 'food and feed' (88\%), while 12\% were for industrial and other purposes (only two applications were for cultivation). Maize has the most applications (51\%); followed by soy beans (21\%); cotton (12\%); potato (3\%); with the remaining 13\% comprising: sugar beet, flowers, and rice.

\section{$<<$ INSERT TABLE 4 HERE $>>$}

We followed a similar strategy for testing the robustness of the trend observed in Figure S5 (online): a convex development for the overall approval time, with long durations for submissions during 1996 and 1998, and the absence of a clear trend for the remaining period. We modelled this relationship in model 1, our baseline model, with two metric variables: 'year' and the 'square of the year' expecting them to have negative and positive signs, respectively, indicating the aforementioned convex-shaped relationship. Signs and sizes of the variables: 'year' and 'year (squared)' confirm the development of a convex shape (Table S8, on-line). We added variables for controlling other potential effects such as the developer's domicile; the crop's GE trait; and the crop's intended use ('food and feed' vs. non-food/feed). We found that some crop features are correlated with the time taken to complete the Member State-application step: applications for 
maize took $82 \%$ (15 days) longer than those for soy beans, while applications with the trait insect resistance took 150\% (88 days) longer than those for herbicide tolerance. Similarly, applications for non-food/feed took $208 \%$ (559 days) longer than those for 'food and feed' purposes.

For the 'risk assessment' step we used a linear-only time variable and found that the corresponding coefficient suggests a statistically significant, positive slope (Table S9, on-line). This coefficient is robust in models 1-4, but loses robustness when crop type is included (model 5). We used maize as our reference category and found that only applications for cotton, soy beans and 'other plant' category correlate with the time taken to complete the 'risk assessment' step and that these crops took $53 \%$ and $35 \%$ longer and $43 \%$ less time compared with maize, respectively.

Results presented in Table S10, (on-line) indicate a negatively-sloping linear relationship for the 'political' step. We captured this trend with a metric variable measuring the change in approval time by year. The results confirm our observation showing that with every additional year, the approval time decreases by 7-8\% (35-48 days): a robust finding for all five models. There is evidence in this model that applications for multiple traits took somewhat longer compared with the single trait category. Coefficients for cotton and potato (model 5) are statistically significantly different to maize, meaning that completing this step took approximately 49\% (163 days) and 118\% (977 days) longer for these applications, respectively, compared with maize.

When analyzing the total time for approving a GE crop, we expect the regression results to conform to the result of the Member State-application step. Results presented in Table S11 (on-line) confirm the concave trend in overall approval time; coefficients in all models are statistically significant and all have the expected signs. Comparing these results with those in Tables S8-S10 (on-line) suggests that the Member State-application step drives the reduction in approval time; the 'risk assessment' and 'political' steps contribute to the overall time, but only marginally (if anything) to the observed changes in duration.

Single trait applications required 15-22\% less time (206-375 days), confirming earlier findings shown in Table S9 (on-line); applications for potatoes and cotton took about 54\% (1,273 days) and $49 \%$ (1,021 days) longer, respectively. For the overall time, we find no robust evidence for statistically significant differences between domestic and foreign developers, herbicide tolerant and insecticide resistant crops, or 'food and feed' and non-food/feed crops.

\subsection{US-EU Contrasts}

The regulatory systems of the US and EU are inherently different (see Section 2). No applications in our dataset were submitted simultaneously in both jurisdictions. Applications in the US include cultivation as a use in distinct contrast to the EU where only two applications were for this purpose. 
We avoid drawing direct comparisons of the total time taken for GE crops passing through these regulatory pipelines because it is theoretically flawed due to endogenous inconsistencies. However, because the 'bureaucratic' step in the US is similar to the EU's 'risk assessment' step, we computed the mean time taken for the same GE events, a subset of 26, to have completed these steps (all of the events in this subset were approved in the US first; their subsequent applications in the EU were for 'import' and or 'food and feed' use), yielding 686 days in the US compared with 995 days in the EU, a difference of 309 days.

\section{Results and Discussion}

Generally, the development and commercialization of new GE crops is hampered by slow and costly approval processes (Kalaitzandonakes et al., 2007). A trend towards shorter approval times in a given regulatory system is expected (Pray et al., 2005), as experience with the different steps in the approval process, in scientific research, and the commercialization of GE crops is gained with time, thus allowing efficiencies to develop (Bradford et al., 2005; Giddings et al., 2013). Our analysis of all the approved GE crops in the US to the end of 2015 shows this trend during the period 1988-1997, decreasing by an average of 114 days annually. Surprisingly, from 1998 onwards, the overall trend virtually stagnates with approval periods getting only slightly quicker by an average of approximately five days annually (Table 1, Figure S4, on-line). This break in the trend coincides with a number of disruptive events in the biotechnology arena. Examples from the US include the Prodigene (Federation of American Scientists, 2011) and StarLink (Carter and Smith, 2007) incidents, and the monarch butterfly controversy; and from the EU, which is an important trade destination of GE products from the US: the researcher Pusztai's work on the health effect of GM potatoes on rats; the de facto moratorium on new GE crop authorizations spawning new legislation (explicitly incorporating the precautionary principle and broadening the criteria for risk assessments) (Devos et al., 2006); “debates over Dolly the sheep and GM crops and food” (Bauer, 2002), and the occurrence of bovine spongiform encephalopathy ${ }^{3}$. Interestingly, a similar phenomenon occurred with the worldwide number of active new GE product quality innovations in the agricultural biotechnology arena, which grew exponentially until 1998 when its declining trend suddenly levelled off (Graff et al., 2009).

It is surprising that over time, the EU's approval process has tended to shorten (Figure S5, online), as there is considerable consumer and political resistance to adopting GE crops in this region,

\footnotetext{
${ }^{3}$ The Economist. Available from: http://www.economist.com/node/436033/print (Europe's mad cows, 2000, last accessed 06 April 2015).
} 
which is heterogeneous in terms of attitudes towards GE crops (Devos et al., 2006). In the EU, it is permissible for developers to reference data or "notifications previously submitted by other notifiers" (Council Directive 2001/18/EC) when conducting their scientific investigations - a positive information spill-over effect. The duration of the 'risk assessment' step has tended to increase (Figure S5 (b), on-line), thus finding ways to shorten this step will reduce the EU's overall regulatory time.

We found one regulatory change in the US aimed at shortening the approval time of GE crops. An internal inquiry by the APHIS showed "competing priorities for ... staff" as a probable cause for the 'bureaucratic' step taking longer (Capital Reporting Company, 2011), which subsequently led the APHIS to introduce procedural changes to the US's petition process in 2012 (compare Figure S1 with S2, on-line). It will be interesting to see if these alterations reach the USDA's goal of improving customer service (USDA APHIS, 2012), and by implication, regulatory efficiency —one measure of which would be the speeding up of the 'bureaucratic' step.

\section{Conclusion}

Repeated calls have been made for the regulatory trigger to be product- rather than process based (e.g. Bradford et al., 2005; House of Commons, 2015), i.e. to regulate the transgenic event and not the plant being altered — an important focus area, as of July 2015, officially mentioned by the US government (Office of Science and Technology Policy, 2015). This change to the 'scientific' step has the potential for speeding up the approval of GE plants, since duplicating costly and lengthy scientific inquiries would be eliminated. This can reduce asynchronicity in the approval of GE crops, and therefore positively contribute to the international trade environment, especially as most GE crops are first developed in the US.

An analysis of the EFSA's 'risk assessment' step is required to investigate if its completiontime can be shortened. In principle, the EU's regulatory path could end at the EFSA. However, a subsequent 'political' step exists, which, if shortened or even eliminated would also contribute to speeding up the EU's regulatory time. The 'opt-out' legislation introduced in 2015 allows Member States to restrict or prohibit the cultivation of EU-approved GE crops on their territories (Directive (EU) 215/412), which Dederer (2016) suggests adds nothing to the "additional value" of the existing framework. This policy change can accelerate the 'political' step as Member States can approve applications for cultivation at their first voting opportunity at the SCFCAH. However, it seems doubtful if this regulation will impact approval times considering the fairly rigid voting behaviour of EU Member States (Smart et al., 2015). 
Our results suggest that political decision-makers in the EU and the US should consider implementing policies making their regulatory process more affordable. This can be achieved without compromising safety. The increase in approval time seems to have been caused by events in the late 1990s and early 2000s. Human resources handling applications in the US have been reduced, which partially explains an increase in approval time. We offer two additional explanations: (1) staff handling applications may have become more cautious as a result of the events that occurred in the late 1990s and early 2000s; and (2) opening up the approval process for public comments in the mid-2000s slowed down approval time as those comments needed to be addressed and required additional human resources, which had already been identified as a limiting factor. Since the science did not change, such an improvement in shortening approval time would stimulate and encourage investment in agricultural innovation by smaller investors and in a broader spectrum of products - currently restricted to a few, large firms focusing their efforts both on a narrow range of crops and genetic attributes (Bradford et al., 2005) and contribute substantial economic benefits (Zilberman et al., 2015).

The US is the locus for most of these biotech innovations (Graff et al., 2009), from which they diffuse globally. The US's rate of commercialization of new GE crops depends not only upon its regulatory system, but also on the compliance requirements of other countries being concurrently addressed by US developers. For society to gain from these innovations earlier in countries adopting this technology, measures for speeding up their regulatory processes need to be found and implemented (Wesseler and Kalaitzandonakes, 2011). Our results support the US government's July 2015 plan for modernizing its regulatory system for biotechnology products, especially its focus on reducing regulatory burdens for small and mid-sized firms (Office of Science and Technology Policy, 2015) and its subsequent announcement to review its regulations to eliminate "unnecessary regulatory burdens" in general (Animal and Plant Health Inspection Service, 2016). If this could be achieved, not only the US but also other countries such as the EU would benefit. 


\section{References}

Agrafacts. Available at: http://www.agrafacts.com/Home.html (2015, last accessed 07 July 2015).

Animal and Plant Health Inspection Service. 'Environmental Impact Statement; Introduction of the Products of Biotechnology', Federal Register 81(24), (2016) pp. 6225-6229.

Bauer, M.W. 'Controversial medical and agri-food biotechnology: a cultivation analysis', Public Understand of Science, Vol. 11, (2002) pp. 93-111.

Bayer, J.C., Norton, G.W. and Falck-Zepeda, J.B. 'Cost of Compliance with Biotechnology Regulation in the Philippines: Implications for Developing Countries', AgBioForum, Vol. 13(1), (2010) pp. 53-62.

Benbrook, C.M. 'Impacts of genetically engineered crops on pesticide use in the US - the first sixteen years', Environmental Sciences Europe, Vol. 24(24), (2012) pp. 1-13.

Bennett, A.B., Chi-Ham, C., Barrows, G., Sexton, S. and Zilberman, D. 'Agricultural Biotechnology: Economics, Environment, Ethics, and the Future', Annual Review of Environment and Resources, Vol. 38, (2013) pp. 249-279.

Bonneuil, C., Joly, P-B. and Marris, C. 'Disentrenching Experiment. The construction of GM-Crop field trials as a social problem', Science, Technology, and Human Values, Vol. 33(2), (2008) pp. 201-229.

Bradford, K.J., Van Deynze, A., Gutterson, N., Parrott, W. and Strauss, S.H. 'Regulating transgenic crops sensibly: lessons from plant breeding, biotechnology and genomics', Nature Biotechnology, Vol. 23, (2005) pp. 439-444.

Brookes, G. and Barfoot, P. GM crops: global socio-economic and environmental impacts 19962012. Available at: http://www.pgeconomics.co.uk/ (Dorchester, UK, 2014, last accessed 07 July 2015).

Capital Reporting Company. Biotechnology Regulatory Services, Public Stakeholder Meeting 1213-2011. Available at: 
http://www.aphis.usda.gov/biotechnology/downloads/Meetings/brs_public_stakeholder_mtg 121311.pdf (USDA Center, Riverdale, Maryland, 2011, last accessed 06 July 2015).

Cararu, J.G. 'Lack of Sherpas for a GMO Escape Route in the EU', German Law Journal, Vol. 10(8), (2009) pp. 1169-1199.

Carter, C.A. and Smith, A. 'Estimating the market effect of a food scare: the case of genetically modified StarLink corn', The Review of Economics and Statistics, Vol. 89(3), (2007) pp. 522533. Available at: doi/pdf/10.1162/rest.89.3.522 (last accessed 06 April 2015).

Council Directive 2001/18/EC of the European Parliament and of the Council of 12 March 2001 on the deliberate release into the environment of genetically modified organisms and repealing Council Directive 90/220/EEC. Official Journal of the European Communities, L 106, (2001) pp. 1-38.

Council Regulation (EC) No 178/2002 of the European Parliament and of the Council of 28 January 2002 laying down the general principles and requirements of food law, establishing the European Food Safety Authority and laying down procedures in matters of food safety. Official Journal of the European Communities, L 31, (2002) pp. 1-24.

Davison, J. 'GM plants: Science, politics and EC regulations', Plant Science, Vol. 178(2) (2010) pp. 94-98.

Dederer, H. 'The Challenge of Regulating Genetically Modified Organisms in the European Union: Trends and Issues', in Y. Nakanishi (ed.) Contemporary Issues in Environmental Law, Environmental Protection in the European Union 5, The EU and Japan (Tokyo, Japan, 2016, pp.139-168). Available at: DOI 10.1007/978-4-431-55435-6_8 (last accessed 23 February 2016).

de Faria, R.N. and Wieck, C. 'Empirical evidence on the trade impact of asynchronous regulatory approval of new GMO events', Food Policy, Vol. 53, (2015) pp. 22-32.

DeFrancesco, L. 'US Congress moves to 'protect' GM crop plantings', Nature Biotechnology, Vol. 31(6), (2013) p. 479.

Directive (EU) 2015/412 of the European Parliament and of the Council of 11 March 2015 amending Directive 2001/18/EC as regards the possibility for the Member States to restrict or 
prohibit the cultivation of genetically modified organisms (GMOs) in their territory. Official Journal of the European Communities, L 68, (2015) pp. 1-8.

De Steur, H., Blancquaert, D., Strobbe, S, Lambert, W., Gellynck, X. and Van Der Straeten, D. 'Status and market potential of transgenic biofortified crops', Nature Biotechnology, Vol. 33(1), (2015) pp. 25-29.

Devos, Y., Reheul, D., De Waele, D. and Van Speybroeck, L. 'The interplay between societal concerns and the regulatory frame on GM crops in the European Union', Environmental Biosafety Research, Vol. 5(3), (2006) pp. 127-149.

EFSA. Genetically Modified Organisms. Available at: http://www.efsa.europa.eu/en/topics/topic/gmo (EFSA's role and activities, 2015, last accessed 06 April 2015).

European Commission. GMO authorisations for cultivation. Available at: http://ec.europa.eu/food/plant/gmo/authorisation/cultivation/index_en.htm (2016, last accessed 08 February 2016).

European Commission. Comitology committees Appeal Committee. Available at: http://ec.europa.eu/dgs/health_food-safety/dgs_consultations/regulatory_committees_en.htm (2015, last accessed 06 April 2015).

Federation of American Scientists. Case Studies in Agricultural Biosecurity. Available at: http://www.fas.org/biosecurity/education/dualuse-agriculture/2.-agriculturalbiotechnology/prodigene-incident.html (The Prodigene Incident, 2011, last accessed 06 April 2015).

Graff, G.D., Zilberman, D. and Bennett, A.B. 'The contraction of agbiotech product quality innovation', Nature Biotechnology, Vol. 8, (2009) pp. 702-704.

Henseler, M., Piot-Lepetit, I., Ferrari, E., Mellado, A.G., Banse, M., Grethe, H., Parisi, C. and Hélaine, S. 'On the asynchronous approvals of GM crops: potential market impacts of a trade disruption of EU soy imports', Food Policy, Vol. 41, (2013) pp. 166-176.

House of Commons. Advanced genetic techniques for crop improvement: regulation, risk and precaution. Available at:

http://www.publications.parliament.uk/pa/cm201415/cmselect/cmsctech/328/328.pdf, 
(London: Science and Technology Committee, Fifth Report of Session 2014-15, HC 328, 2015, last accessed 15 February 2016).

Giddings, L.V., Stepp, M. and Caine, M. Feeding the planet in a warming world. Building resilient agriculture through innovation, (The Information Technology \& Innovation Foundation and The London School of Economics and Political Science, 2013). Available at: http://www2.itif.org/2013-feeding-planet-warming-world.pdf (last accessed 06 July 2015).

GMO Compass. Available at: http://www.gmo-compass.org/eng/gmo/db/ (GMO Database, 2016, last accessed 08 February 2016).

Kalaitzandonakes, N., Alston, J.M. and Bradford, K.J. 'Compliance costs for regulatory approval of new biotech crops', Nature Biotechnology, Vol. 25(5), (2007) pp. 509-511.

Klümper, W. and Qaim, M. 'A Meta-Analysis of the Impacts of Genetically Modified Crops', PLoS ONE, Vol. 9(11), (2014) e111629.

Lynch, D. and Vogel, D. The Regulation of GMOs in Europe and the United States: A Case-Study of Contemporary European Regulatory Politics, (Council on Foreign Relations, 2001). Available at: http://www.cfr.org/agricultural-policy/regulation-gmos-europe-united-statescase-study-contemporary-european-regulatory-politics/p8688 (last accessed_27 April 2015).

Mannion, A.M. and Morse, S. GM Crops 1996-2012: A Review of Agronomic, Environmental and Socio-economic Impacts, Working Paper 04/13 / Geographical Paper No. 195 (University of Surrey, Centre for Environmental Strategy (CES) / University of Reading, 2013). Available at: https://www.surrey.ac.uk/ces/files/pdf/04-13\%20Morse_Mannion_GM\%20Crops.pdf (last accessed 07 July 2015).

Miller, J.K. and Bradford, K.J. 'The regulatory bottleneck for biotech specialty crops', Nature Biotechnology, Vol 28 (10), (2010) pp. 1012-1014.

Morris, S. and Spillane, C. 'EU GM crop regulation: a road to resolution or a regulatory roundabout?', European Journal of Risk Regulation, Vol. 4, (2010) pp. 359-369.

Nowicki, P., Aramyan, L., Baltussen, W., Dvortsin, L., Jongeneel, R., Pérez Domínguez, I., van Wagenberg, C., Kalaitzandonakes, N., Kaufman, J., Miller, D., Franke, L. and Meerbeek, B. Study on the Implications of Asynchronous GMO Approvals for EU Imports of Animal Feed 
Products, Directorate-General for Agriculture and Rural Development, European

Commission, Final Report (Contract No. 30-CE-0317175/00-74) (2010).

Office of Science and Technology Policy. 'Coordinated framework for regulation of biotechnology products', Federal Register 51(1986) p. 23302. Available at:

http://www.epa.gov/biotech_rule/pubs/pdf/coordinated-framework-1986.pdf (last accessed 07 July 2015).

Office of Science and Technology Policy. Modernizing the Regulatory System for Biotechnology

Products, Memorandum for Heads of Food and Drug Administration, Environmental

Protection Agency, and Department of Agriculture (Executive Office of the President of the United States, 2015). Available at:

https://www.whitehouse.gov/sites/default/files/microsites/ostp/modernizing the_reg_system for_biotech_products_memo_final.pdf (last accessed 10 July 2015).

Phillips McDougall. The cost and time involved in the discovery, development and authorisation of a new plant biotechnology derived trait, (A Consultancy Study for Crop Life International, 2011). Available at: https://croplife.org/wp-content/uploads/2014/04/Getting-a-Biotech-Cropto-Market-Phillips-McDougall-Study.pdf (last accessed 08 February 2016).

Pray, C.E., Bengali, P. and Ramaswami, B. 'The cost of biosafety regulations: the Indian experience', Quarterly Journal of International Agriculture, Vol. 44(3), (2005) pp. 267-289.

Punt, M. and Wesseler, J. 'Legal but costly: An analysis of the EU GM regulation in the light of the WTO trade dispute between the EU and the US', World Economy, Vol. 39(1), (2016) pp. 158169.

Smart, R.D., Blum, M. and Wesseler, J. 'EU Member States' Voting for Authorizing Genetically Engineered Crops: a Regulatory Gridlock', German Journal of Agricultural Economics, Vol. 64(4), (2015) pp. 242-262.

Stein, A.J. and Rodríguez-Cerezo, E. International trade and the global pipeline of new GM crops. Implications of asynchronous approval for international trade, (Luxembourg: Office for Official Publications of the European Communities, 2009).

The European Association for Bioindustries. Approvals of GMOs in the European Union, (EuropaBio, 2011). Available at: http://www.europabio.org/sites/default/files/approvals_of_gmos_in_eu_europabio_report.pdf (last accessed 28 May 2015). 
USDA. Available at: http://www.aphis.usda.gov/biotechnology/petitions_table_pending.shtml (Petitions for Determination of Nonregulated Status, 2016a, last accessed 08 February 2015).

USDA. Available at:

https://www.aphis.usda.gov/aphis/ourfocus/biotechnology/sa_permits_notifications_and_petit ions/sa_permits/ct_status (Check Status, 2016b, last accessed 08 February 2016).

USDA APHIS. 2010. Monsanto Company and KWS SAAT AG; Supplemental Request for Partial Deregulation of Roundup Ready Sugar Beet, 75 FR 62365. Available at: https://www.gpo.gov/fdsys/pkg/FR-2010-10-08/pdf/2010-25387.pdf (2010, last accessed 06 April 2015).

USDA APHIS. 2011. Determination of Regulated Status of Alfalfa Genetically Engineered for Tolerance to the Herbicide Glyphosate; Record of Decision, 76 FR 5780. Available at: https://www.gpo.gov/fdsys/pkg/FR-2011-02-02/pdf/2011-2268.pdf (2011, last accessed 06 April 2015).

USDA APHIS. 2012. Changes Regarding the Solicitation of Public Comment for Petitions for Determinations of Nonregulated Status for Genetically Engineered Organisms, 77 FR 13258. 
available at: http://www.aphis.usda.gov/brs/fedregister/BRS_20120306.pdf (2012, last accessed 06 April 2015).

Vigani, M. and Olper, O. 'GMO standards, endogenous policy and the market for information', Food Policy. Vol. 43, (2013) pp. 32-43.

Vigani, M. and Olper, O. 'Patterns and Determinants of GMO Regulations: An Overview of Recent Evidence', AgBioForum. Vol. 18(1), (2015) pp. 44-54.

Vigani, M., Raimondi, V. and Olper, A. 'International trade and endogenous standards: the case of GMO regulations', World Trade Review. Vol. 11, (2012) pp. 415-437.

Wesseler, J. and Kalaitzandonakes, N. 'Present and Future EU GMO policy', in A. Oskam, G. Meesters and H. Silvis (eds.), EU Policy for Agriculture, Food and Rural Areas (Second Edition, Wageningen: Wageningen Academic Publishers, 2011, pp. 323-332).

Wesseler, J., Scatasta, S. and Fall, E. 'Environmental Benefits and Costs of GM Crops', in C. Carter, G. Moschini and I. Sheldon (eds.), Genetically modified food and global welfare, Bingley, UK: Emerald Group Publishing, 2011, pp. 173-199.

Wesseler, J. and Zilberman, D. 'The economic power of the Golden Rice Opposition', Environment and Development Economics. Vol. 19(6), (2014) pp. 724-742.

Zilberman, D., Kaplan, S. and Wesseler, J. 'The Loss from Underutilizing GM technologies', AgBioForum. Vol. 18(3), (2015) pp. 312-319. 
Table 1

Mean time (days) taken (and their mean annual changes indicated in parentheses) for completing the regulatory process for GE crops approved in the US ${ }^{\mathrm{a}}$ from 1988-2015.

\begin{tabular}{|l|r|r|r|}
\hline Period & $\begin{array}{r}\text { Field Trial Phase } \\
\text { (days) }\end{array}$ & $\begin{array}{c}\text { Petition Phase } \\
\text { (days) }\end{array}$ & $\begin{array}{c}\text { Entire Process } \\
\text { (days) }\end{array}$ \\
\hline Early: $1988-1997$ & 1,110 & 210 & 1,321 \\
& $(-102.0)$ & $(-6.2)$ & $(-108.2)$ \\
& $\mathrm{n}=40$ & $\mathrm{n}=40$ & $\mathrm{n}=40$ \\
\hline Late: $1998-2015$ & 1,614 & 889 & 2,467 \\
& $(-20.2)$ & $(16.5)$ & $(-4.7)$ \\
& $\mathrm{n}=52$ & $\mathrm{n}=53$ & $\mathrm{n}=51$ \\
\hline
\end{tabular}

${ }^{a}$ Data source: http://www.aphis.usda.gov/biotechnology/status.shtml.

Table 2

Mean time (days) taken for completing the regulatory process for GE crops approved in the EU from 1996-2015.

\begin{tabular}{|l|r|r|r|r|}
\hline Period & $\begin{array}{c}\text { Application at } \\
\text { MS } \\
\text { (days) }\end{array}$ & $\begin{array}{c}\text { Risk Assessment } \\
\text { (at EFSA from 2002) } \\
\text { (days) }\end{array}$ & $\begin{array}{c}\text { Risk Management } \\
\text { (EU Commission) } \\
\text { (days) }\end{array}$ & $\begin{array}{c}\text { Entire Process } \\
\text { (days) }\end{array}$ \\
\hline $1988-2015$ & 263 & 929 & 594 & 1,763 \\
$\mathrm{n}=65$ & $\mathrm{n}=68$ & $\mathrm{n}=62$ & $\mathrm{n}=58$ \\
\hline
\end{tabular}

a Data sources: http://www.gmo-compass.org/eng/gmo/db/; EFSA Journal; Official Journal of the European Union. 
Table 3

Descriptive statistics for the US's dataset for the time taken for GE crops passing through the regulatory process, and those awaiting the outcome of the 'bureaucratic' step.

\begin{tabular}{|c|c|c|c|c|}
\hline Category & Parameter & Mean & Min & Max \\
\hline \multirow{3}{*}{$\begin{array}{l}\text { Regulatory step's } \\
\text { duration }\end{array}$} & Scientific step (ln) & $\begin{array}{r}7.16 \\
(0.41)\end{array}$ & 5,58 & 8,06 \\
\hline & Political step (ln) & $\begin{array}{r}6.05 \\
(0.84)\end{array}$ & 4,67 & 7,58 \\
\hline & Overall process $(\ln )$ & $\begin{array}{r}7.49 \\
(0.45) \\
\end{array}$ & 6,1 & 8,42 \\
\hline \multirow{2}{*}{$\begin{array}{l}\text { Developer's } \\
\text { domicile }\end{array}$} & Domestic & $\begin{array}{r}0.75 \\
(0.44)\end{array}$ & 0 & 1 \\
\hline & Foreign & $\begin{array}{r}0.25 \\
(0.44)\end{array}$ & 0 & 1 \\
\hline \multirow[t]{2}{*}{ Trait multiple } & Single & $\begin{array}{r}0.69 \\
(0.47)\end{array}$ & 0 & 1 \\
\hline & Multiple & $\begin{array}{r}0.31 \\
(0.47) \\
\end{array}$ & 0 & 1 \\
\hline \multirow[t]{3}{*}{ Trait type } & Herbicide tolerant & $\begin{array}{l}0.51^{\mathrm{a}} \\
(0.5) \\
\end{array}$ & 0 & 1 \\
\hline & Insect resistant & $\begin{array}{r}0.32^{\mathrm{a}} \\
(0.47) \\
\end{array}$ & 0 & 1 \\
\hline & Other trait & $\begin{array}{r}0.32^{\mathrm{a}} \\
(0.47) \\
\end{array}$ & 0 & 1 \\
\hline \multirow[b]{2}{*}{ Crop's use } & Food & $\begin{array}{r}0.79 \\
(0.41)\end{array}$ & 0 & 1 \\
\hline & Non-food & $\begin{array}{r}0.21 \\
(0.41) \\
\end{array}$ & 0 & 1 \\
\hline \multirow{6}{*}{ Crop } & Cotton & $\begin{array}{r}0.17 \\
(0.37)\end{array}$ & 0 & 1 \\
\hline & Maize & $\begin{array}{r}0.32 \\
(0.47) \\
\end{array}$ & 0 & 1 \\
\hline & Soy & $\begin{array}{r}0.18 \\
(0.38) \\
\end{array}$ & 0 & 1 \\
\hline & Tomato & $\begin{array}{r}0.06 \\
(0.24) \\
\end{array}$ & 0 & 1 \\
\hline & Potato & $\begin{array}{r}0.06 \\
(0.24) \\
\end{array}$ & 0 & 1 \\
\hline & Other & $\begin{array}{r}0.21 \\
(0.41) \\
\end{array}$ & 0 & 1 \\
\hline
\end{tabular}

${ }^{a}$ The sum of these coefficients is $>1.0$. This is because of stacked events where one trait is represented in two categories simultaneously (e.g. herbicide tolerance and insect resistance together in a stacked event). 
Table 4

Descriptive statistics for the EU's dataset for the time taken for GE crops passing through the regulatory process, and those awaiting the outcome of the 'political' step.

\begin{tabular}{|c|c|c|c|c|}
\hline Category & Parameter & Mean & Min & Max \\
\hline \multirow{6}{*}{$\begin{array}{l}\text { Regulatory step's } \\
\text { duration }\end{array}$} & MS Application (ln) & $\begin{array}{r}3.54 \\
(107)\end{array}$ & 0,69 & 7,94 \\
\hline & Risk Assessment (ln) & 6.64 & 5,07 & 7,87 \\
\hline & & $(0.66)$ & & \\
\hline & Risk Management (ln) & 6.14 & 4,78 & 7,68 \\
\hline & & $(0.71)$ & & \\
\hline & Overall process (ln) & $\begin{array}{r}7.38 \\
(0.42)\end{array}$ & 6,47 & 8,51 \\
\hline \multirow[b]{2}{*}{ Developer's domicile } & Domestic & $\begin{array}{r}0.32 \\
(0.47)\end{array}$ & 0 & 1 \\
\hline & Foreign & $\begin{array}{r}0.68 \\
(0.47)\end{array}$ & 0 & 1 \\
\hline \multirow[t]{2}{*}{ Trait multiple } & Single & $\begin{array}{r}0.51 \\
(0.48)\end{array}$ & 0 & 1 \\
\hline & Multiple & $\begin{array}{r}0.49 \\
(0.48)\end{array}$ & 0 & 1 \\
\hline \multirow{3}{*}{ Crop trait } & Herbicide tolerant & $\begin{array}{r}0.72^{*} \\
(0.45)\end{array}$ & 0 & 1 \\
\hline & Insect resistant & $\begin{array}{r}0.51^{*} \\
(0.50)\end{array}$ & 0 & 1 \\
\hline & Other trait & $\begin{array}{c}0.16^{*} \\
(0.37)\end{array}$ & 0 & 1 \\
\hline \multirow[t]{2}{*}{ Crop's use } & Food & $\begin{array}{r}0.88 \\
(0.32)\end{array}$ & 0 & 1 \\
\hline & Non-food & $\begin{array}{r}0.12 \\
(0.32)\end{array}$ & 0 & 1 \\
\hline \multirow{6}{*}{ Crop } & Cotton & $\begin{array}{r}0.12 \\
(0.32)\end{array}$ & 0 & 1 \\
\hline & Maize & $\begin{array}{r}0.51 \\
(0.5)\end{array}$ & 0 & 1 \\
\hline & Soy & $\begin{array}{r}0.21 \\
(0.41)\end{array}$ & 0 & 1 \\
\hline & Potato & 0.03 & 0 & 1 \\
\hline & & $(0.17)$ & & \\
\hline & Other & $\begin{array}{r}0.13 \\
(0.34)\end{array}$ & 0 & 1 \\
\hline
\end{tabular}

*The sum of these coefficients is $>1.0$, because of stacked events where one trait is represented in two categories simultaneously (e.g. herbicide tolerance and insect resistance together). 
Table S5: Correlates of time taken to for completing the scientific (field trial) step of the GE crop approval process in the US, 1988-2012.

\begin{tabular}{|c|c|c|c|c|c|}
\hline \multirow[b]{2}{*}{ Variables } & (1) & (2) & (3) & (4) & (5) \\
\hline & \multicolumn{5}{|c|}{ Days for scientific step (natural log) } \\
\hline Early & $\begin{array}{c}-0.38 * * * \\
(0.000)\end{array}$ & $\begin{array}{c}-0.41 * * * \\
(0.000)\end{array}$ & $\begin{array}{c}-0.40 * * * \\
(0.000)\end{array}$ & $\begin{array}{c}-0.42 * * * \\
(0.000)\end{array}$ & $\begin{array}{c}-0.37 * * * \\
(0.000)\end{array}$ \\
\hline Late & reference & reference & reference & reference & reference \\
\hline Domestic & & $\begin{array}{c}0.02 \\
(0.821)\end{array}$ & $\begin{array}{c}0.04 \\
(0.683)\end{array}$ & $\begin{array}{c}0.03 \\
(0.797)\end{array}$ & $\begin{array}{c}-0.02 \\
(0.852)\end{array}$ \\
\hline Foreign & reference & reference & reference & reference & reference \\
\hline Single trait & & $\begin{array}{c}0.16^{*} \\
(0.091)\end{array}$ & $\begin{array}{c}0.16 \\
(0.161)\end{array}$ & $\begin{array}{c}0.18 \\
(0.108)\end{array}$ & $\begin{array}{c}0.24 * * * \\
(0.008)\end{array}$ \\
\hline $\begin{array}{l}\text { Multiple trait } \\
\text { Cotton }\end{array}$ & reference & reference & reference & reference & $\begin{array}{c}\text { reference } \\
\quad-0.15 \\
(0.128)\end{array}$ \\
\hline Maize & & & & & reference \\
\hline Soy & & & & & $\begin{array}{c}0.04 \\
(0.691)\end{array}$ \\
\hline Tomato & & & & & $\begin{array}{c}-0.11 \\
(0.263)\end{array}$ \\
\hline Potato & & & & & $\begin{array}{c}0.06 \\
(0.679)\end{array}$ \\
\hline Other crops & & & & & $\begin{array}{c}-0.35^{* *} \\
(0.011)\end{array}$ \\
\hline $\begin{array}{l}\text { Herbicide } \\
\text { tolerant }\end{array}$ & & & $\begin{array}{c}0.02 \\
(0.881)\end{array}$ & $\begin{array}{c}0.01 \\
(0.933)\end{array}$ & \\
\hline Insect resistance & & & reference & reference & \\
\hline Other trait & & & $\begin{array}{c}-0.09 \\
(0.328)\end{array}$ & $\begin{array}{c}-0.10 \\
(0.258)\end{array}$ & \\
\hline Food & & & & $\begin{array}{c}0.13 \\
(0.196)\end{array}$ & \\
\hline Non-food & & & & reference & \\
\hline Constant & $\begin{array}{c}7.33^{* * * *} \\
(0.000)\end{array}$ & $\begin{array}{l}7.22 * * * \\
(0.000)\end{array}$ & $\begin{array}{l}7.22 * * * \\
(0.000)\end{array}$ & $\begin{array}{c}7.13 * * * \\
(0.000)\end{array}$ & $\begin{array}{c}7.27 * * * \\
(0.000)\end{array}$ \\
\hline Observations & 92 & 92 & 92 & 92 & 92 \\
\hline R-squared & 0.22 & 0.25 & 0.26 & 0.27 & 0.36 \\
\hline
\end{tabular}

Note: Robust p-values in parentheses. ***,**,* indicate statistical significance at the 1,5 , and $10 \%$ levels, respectively. Dependent variable is time taken in days (natural log) for completing the scientific step. Reference category refers to a non-US (foreign) based company, submitting a multiple trait and insect resistant GE plant for non-food use during the period 1998 to 2012 (model 4). 
Table S6: Correlates of time taken for completing the 'bureaucratic' step of the GE crop approval process in the US, 1988-2012.

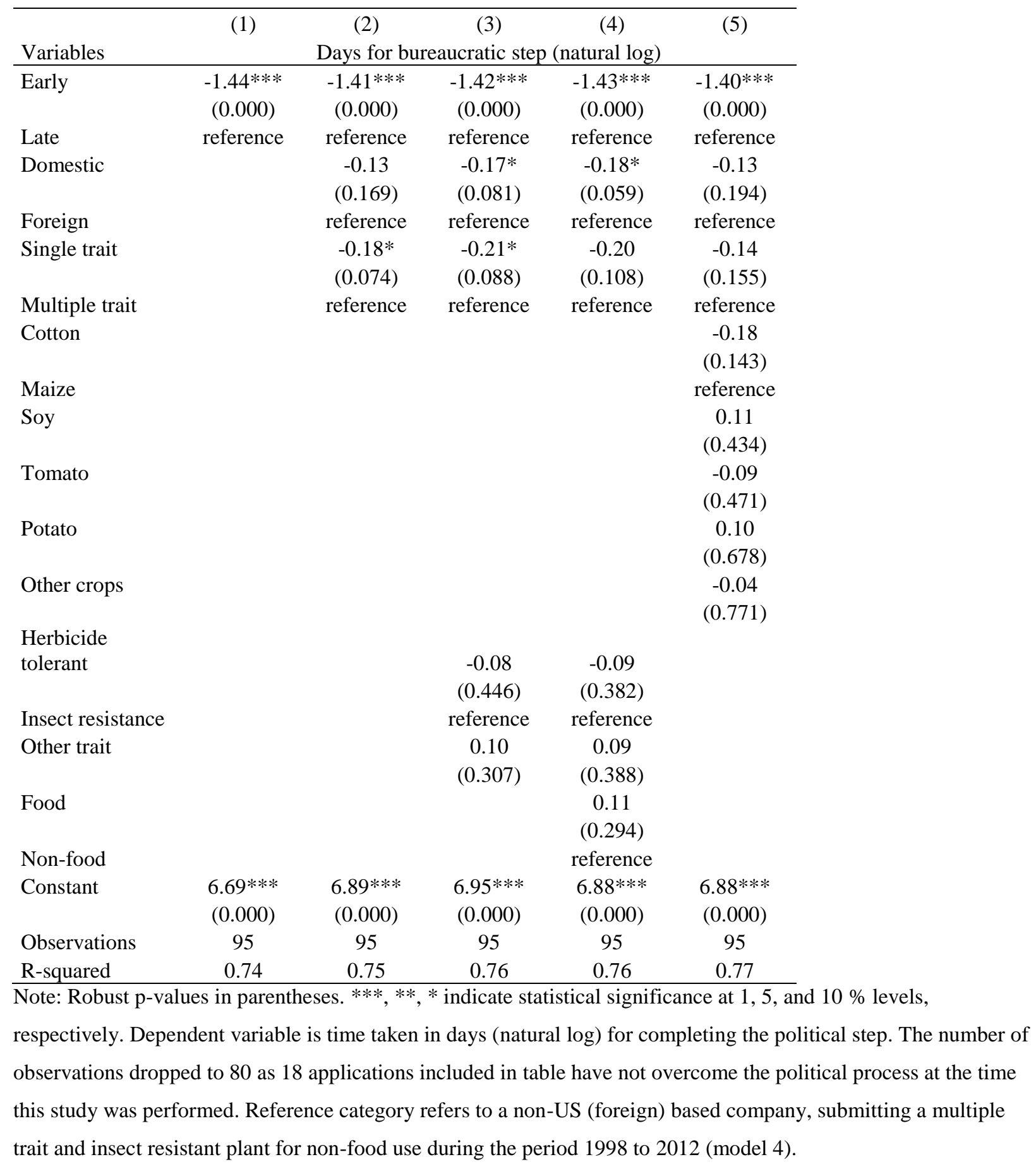


Table S7: Correlates of time taken for completing the overall approval process of GE crops in the

US, 1988-2012.

\begin{tabular}{|c|c|c|c|c|c|}
\hline \multirow[b]{2}{*}{ Variable } & (1) & (2) & (3) & (4) & (5) \\
\hline & \multicolumn{5}{|c|}{ Days for total time taken (natural log) } \\
\hline Early & $\begin{array}{c}-0.63^{* * * *} \\
(0.000)\end{array}$ & $\begin{array}{c}-0.64 * * * \\
(0.000)\end{array}$ & $\begin{array}{c}-0.63 * * * \\
(0.000)\end{array}$ & $\begin{array}{c}-0.65 * * * \\
(0.000)\end{array}$ & $\begin{array}{c}-0.60 * * * \\
(0.000)\end{array}$ \\
\hline Late & reference & reference & reference & reference & reference \\
\hline Domestic & & $\begin{array}{c}-0.01 \\
(0.875)\end{array}$ & $\begin{array}{c}-0.01 \\
(0.923)\end{array}$ & $\begin{array}{c}-0.02 \\
(0.846)\end{array}$ & $\begin{array}{c}-0.05 \\
(0.561)\end{array}$ \\
\hline Foreign & & reference & reference & reference & reference \\
\hline Single trait & & $\begin{array}{c}0.06 \\
(0.470)\end{array}$ & $\begin{array}{c}0.05 \\
(0.624)\end{array}$ & $\begin{array}{c}0.06 \\
(0.521)\end{array}$ & $\begin{array}{c}0.13^{*} \\
(0.080)\end{array}$ \\
\hline $\begin{array}{l}\text { Multiple trait } \\
\text { Cotton }\end{array}$ & & reference & reference & reference & $\begin{array}{c}\text { reference } \\
-0.14 \\
(0.125)\end{array}$ \\
\hline Maize & & & & & reference \\
\hline Soy & & & & & $\begin{array}{c}0.06 \\
(0.497)\end{array}$ \\
\hline Tomato & & & & & $\begin{array}{c}-0.10 \\
(0.237)\end{array}$ \\
\hline Potato & & & & & $\begin{array}{c}0.06 \\
(0.695)\end{array}$ \\
\hline Other crops & & & & & $\begin{array}{c}-0.29 * * * \\
(0.009)\end{array}$ \\
\hline $\begin{array}{l}\text { Herbicide } \\
\text { tolerance }\end{array}$ & & & $\begin{array}{c}-0.02 \\
(0.858)\end{array}$ & $\begin{array}{c}-0.02 \\
(0.820)\end{array}$ & \\
\hline Insect resistance & & & reference & reference & \\
\hline Other trait & & & $\begin{array}{c}-0.05 \\
(0.503)\end{array}$ & $\begin{array}{c}-0.06 \\
(0.445)\end{array}$ & \\
\hline Food & & & & $\begin{array}{c}0.09 \\
(0.339)\end{array}$ & \\
\hline Non-food & & & & reference & \\
\hline Constant & $\begin{array}{l}7.77 * * * \\
(0.000)\end{array}$ & $\begin{array}{c}7.74 * * * * \\
(0.000)\end{array}$ & $\begin{array}{l}7.77 * * * * \\
(0.000)\end{array}$ & $\begin{array}{c}7.70 * * * \\
(0.000)\end{array}$ & $\begin{array}{l}7.77 * * * \\
(0.000)\end{array}$ \\
\hline Observations & 91 & 91 & 91 & 91 & 91 \\
\hline R-squared & 0.50 & 0.50 & 0.50 & 0.51 & 0.57 \\
\hline
\end{tabular}

Note: Robust p-values in parentheses. ${ }^{* *}, * *, *$ indicate statistical significance at 1,5 , and $10 \%$ levels. Dependent variable is time taken in days $(\log )$ to overcome the overall process. The number of observations dropped to 80 here since 18 applications included in this table have not completed the political process at the time that this study was done. Reference category refers to a non-US (foreign) based company, submitting a multiple trait and insect resistant GE plant for non-food use during the period 1998 to 2012 (model 4). 
Table S8: Correlates of time taken for completing MS-application step of the EU's GE crop approval process, 1996-2012.

\begin{tabular}{|c|c|c|c|c|c|}
\hline \multirow[b]{2}{*}{ Variable } & (1) & (2) & (3) & (4) & (5) \\
\hline & \multicolumn{5}{|c|}{ Days for MS-application step (natural log) } \\
\hline Year & $\begin{array}{c}-112.25 * * * \\
(0.000)\end{array}$ & $\begin{array}{c}-94.94 * * * \\
(0.001)\end{array}$ & $\begin{array}{c}-107.16 * * * \\
(0.001)\end{array}$ & $\begin{array}{c}-76.39 * * \\
(0.021)\end{array}$ & $\begin{array}{c}-94.63^{* * * *} \\
(0.005)\end{array}$ \\
\hline Year $^{2}$ & $\begin{array}{r}0.03^{* * *} \\
(0.000)\end{array}$ & $\begin{array}{c}0.02 * * * \\
(0.001)\end{array}$ & $\begin{array}{r}0.03^{* * * *} \\
(0.001)\end{array}$ & $\begin{array}{l}0.02 * * \\
(0.021)\end{array}$ & $\begin{array}{l}0.02 * * * \\
(0.005)\end{array}$ \\
\hline Domestic & & $\begin{array}{l}-0.78^{*} \\
(0.060)\end{array}$ & $\begin{array}{c}-0.56 \\
(0.112)\end{array}$ & $\begin{array}{c}-0.54 \\
(0.126)\end{array}$ & $\begin{array}{l}-0.87 * \\
(0.051)\end{array}$ \\
\hline Foreign & & reference & reference & reference & reference \\
\hline Single trait & & $\begin{array}{l}0.94 * * \\
(0.027)\end{array}$ & $\begin{array}{c}0.29 \\
(0.410)\end{array}$ & $\begin{array}{c}0.54 \\
(0.134)\end{array}$ & $\begin{array}{l}0.82 * * \\
(0.024)\end{array}$ \\
\hline $\begin{array}{l}\text { Multiple trait } \\
\text { Cotton }\end{array}$ & & reference & reference & reference & $\begin{array}{c}\text { reference } \\
0.22 \\
(0.725)\end{array}$ \\
\hline Maize & & & & & reference \\
\hline Soy & & & & & $\begin{array}{c}-0.82 * \\
(0.064)\end{array}$ \\
\hline Potato & & & & & $\begin{array}{c}0.53 \\
(0.337)\end{array}$ \\
\hline Other crop & & & & & $\begin{array}{c}0.83 \\
(0.310)\end{array}$ \\
\hline $\begin{array}{l}\text { Herbicide } \\
\text { tolerance }\end{array}$ & & & $\begin{array}{c}-1.50 * * * \\
(0.000)\end{array}$ & & \\
\hline Insect resistance & & & reference & & \\
\hline Other trait & & & $\begin{array}{c}0.34 \\
(0.559)\end{array}$ & & \\
\hline Food & & & & $\begin{array}{c}-2.08 * * * \\
(0.002)\end{array}$ & \\
\hline Non-food & & & & reference & \\
\hline Constant & $\begin{array}{c}112,854.52 * * * \\
(0.000)\end{array}$ & $\begin{array}{c}95,502.26^{* * *} \\
(0.001)\end{array}$ & $\begin{array}{c}107,736.87 * * * \\
(0.001)\end{array}$ & $\begin{array}{c}76,845.60 * * \\
\quad(0.020)\end{array}$ & $\begin{array}{c}95,133.93^{* * * *} \\
\quad(0.004)\end{array}$ \\
\hline Observations & 64 & 64 & 64 & 64 & 64 \\
\hline R-squared & 0.39 & 0.46 & 0.57 & 0.56 & 0.51 \\
\hline
\end{tabular}

Note: Robust p-values in parentheses. ***, **, * indicate statistical significance at 1, 5, and $10 \%$ levels, respectively. Dependent variable is time taken in days $(\log )$ to overcome the scientific process. Reference category refers to a non-EU (foreign) based company, submitting a multiple trait and insect resistant plant (model 3). 
Table S9: Correlates of time taken for completing the 'risk assessment' step by the EFSA of the EU’s GE crop approval process, 1996-2012.

\begin{tabular}{|c|c|c|c|c|c|}
\hline \multirow{2}{*}{ Variables } & (1) & (2) & (3) & (4) & (5) \\
\hline & \multicolumn{5}{|c|}{ Days for risk assessment step (natural log) } \\
\hline Year & $0.07 * * *$ & $0.07 * * *$ & $0.07 * * *$ & $0.05 * * *$ & 0.04 \\
\hline & $(0.000)$ & $(0.000)$ & $(0.000)$ & $(0.008)$ & $(0.124)$ \\
\hline Domestic & & 0.14 & 0.07 & 0.07 & 0.12 \\
\hline & & $(0.366)$ & $(0.638)$ & $(0.653)$ & $(0.382)$ \\
\hline Foreign & & reference & reference & reference & reference \\
\hline Single trait & & -0.18 & -0.07 & -0.04 & -0.06 \\
\hline & & $(0.254)$ & $(0.668)$ & $(0.788)$ & $(0.690)$ \\
\hline Multiple trait & & reference & reference & reference & reference \\
\hline Cotton & & & & & $\begin{array}{c}0.53 * \\
(0.071)\end{array}$ \\
\hline Maize & & & & & reference \\
\hline Soy & & & & & $0.35^{*}$ \\
\hline & & & & & $(0.063)$ \\
\hline Potato & & & & & $\begin{array}{l}-0.52 \\
(0.338)\end{array}$ \\
\hline Other crops & & & & & $\begin{array}{l}-0.43 * \\
(0.090)\end{array}$ \\
\hline $\begin{array}{l}\text { Herbicide } \\
\text { tolerance }\end{array}$ & & & $\begin{array}{c}0.20 \\
(0.368)\end{array}$ & & \\
\hline Insect resistance & & & reference & & \\
\hline Other trait & & & $\begin{array}{c}-0.24 \\
(0.415)\end{array}$ & & \\
\hline Food & & & & $\begin{array}{c}0.70^{* * *} \\
(0.007)\end{array}$ & \\
\hline Non-food & & & & reference & \\
\hline Constant & $\begin{array}{c}-136.28 * * * \\
(0.000)\end{array}$ & $\begin{array}{c}-139.67 * * * \\
(0.000)\end{array}$ & $\begin{array}{c}-139.97 * * * \\
(0.001)\end{array}$ & $\begin{array}{c}-100.77 * * \\
(0.012)\end{array}$ & $\begin{array}{l}-65.91 \\
(0.161)\end{array}$ \\
\hline Observations & 65 & 65 & 65 & 65 & 65 \\
\hline R-squared & 0.14 & 0.17 & 0.21 & 0.26 & 0.32 \\
\hline
\end{tabular}

Note: Robust p-values in parentheses. ***,**,* indicate statistical significance at 1,5 , and $10 \%$ levels, respectively. Dependent variable is time taken in days (natural log) for passing through the scientific process. Reference category refers to a non-EU (foreign) based company, submitting a multiple trait and insect resistant GE plant (model 3). 
Table S10: Correlates of time taken for completing the 'political' step at the EC of the EU's GE crop approval process, 1996-2012.

\begin{tabular}{|c|c|c|c|c|c|}
\hline \multirow[b]{2}{*}{ Variable } & (1) & (2) & (3) & (4) & (5) \\
\hline & \multicolumn{5}{|c|}{ Days for the political step (natural log) } \\
\hline Year & $\begin{array}{c}-0.08 * * * \\
(0.001)\end{array}$ & $\begin{array}{c}-0.08 * * * \\
(0.001)\end{array}$ & $\begin{array}{c}-0.08 * * * \\
(0.000)\end{array}$ & $\begin{array}{c}-0.08 * * * \\
(0.002)\end{array}$ & $\begin{array}{c}-0.07 * * * \\
(0.003)\end{array}$ \\
\hline Domestic & & $\begin{array}{c}0.13 \\
(0.440)\end{array}$ & $\begin{array}{c}0.19 \\
(0.276)\end{array}$ & $\begin{array}{c}0.13 \\
(0.449)\end{array}$ & $\begin{array}{c}-0.04 \\
(0.779)\end{array}$ \\
\hline Foreign & & reference & reference & reference & reference \\
\hline Single trait & & $\begin{array}{c}-0.39 * * \\
(0.017)\end{array}$ & $\begin{array}{c}-0.49 * * * \\
(0.008)\end{array}$ & $\begin{array}{c}-0.39 * * \\
(0.031)\end{array}$ & $\begin{array}{c}-0.40^{*} \\
(0.059)\end{array}$ \\
\hline $\begin{array}{l}\text { Multiple trait } \\
\text { Cotton }\end{array}$ & & reference & reference & reference & $\begin{array}{c}\text { reference } \\
0.49 * * \\
(0.022)\end{array}$ \\
\hline Maize & & & & & reference \\
\hline Soy & & & & & $\begin{array}{c}0.09 \\
(0.739)\end{array}$ \\
\hline Potato & & & & & $\begin{array}{l}1.18 * * * \\
(0.001)\end{array}$ \\
\hline Other crop & & & & & $\begin{array}{c}-0.14 \\
(0.563)\end{array}$ \\
\hline Herbicide tolerant & & & $\begin{array}{c}-0.06 \\
(0.818)\end{array}$ & & \\
\hline Insect resistance & & & reference & & \\
\hline Other trait & & & $\begin{array}{c}0.35 \\
(0.185)\end{array}$ & & \\
\hline Food & & & & $\begin{array}{c}0.01 \\
(0.985)\end{array}$ & \\
\hline Non-food & & & & reference & \\
\hline Constant & $\begin{array}{c}165.09 \text { *** } \\
(0.001)\end{array}$ & $\begin{array}{c}161.23 * * * \\
(0.001)\end{array}$ & $\begin{array}{c}165.47 * * * \\
(0.000)\end{array}$ & $\begin{array}{c}161.51^{* * * *} \\
(0.001)\end{array}$ & $\begin{array}{c}149.38 * * * \\
(0.002)\end{array}$ \\
\hline Observations & 59 & 59 & 59 & 59 & 59 \\
\hline R-squared & 0.15 & 0.22 & 0.26 & 0.22 & 0.36 \\
\hline
\end{tabular}

Note: Robust p-values in parentheses. $* * *, * *, *$ indicate statistical significance at 1,5 , and $10 \%$ levels, respectively. Dependent variable is time taken in days (natural log) for passing through period 3. 
Table S11: Correlates of time taken for completing the overall approval process for GE crops in the EU, 1996-2012.

\begin{tabular}{|c|c|c|c|c|c|}
\hline \multirow[b]{2}{*}{ Variables } & (1) & $(2)$ & (3) & (4) & (5) \\
\hline & \multicolumn{5}{|c|}{ Days for the overall authorization process (natural log) } \\
\hline Year & $\begin{array}{c}-29.10 * * * \\
(0.001)\end{array}$ & $\begin{array}{c}-35.04 * * * \\
(0.000)\end{array}$ & $\begin{array}{c}-33.23 * * * \\
(0.000)\end{array}$ & $\begin{array}{c}-33.53 * * * \\
(0.000)\end{array}$ & $\begin{array}{c}-30.63 * * * \\
(0.001)\end{array}$ \\
\hline Year $^{2}$ & $\begin{array}{l}0.01 * * * \\
(0.001)\end{array}$ & $\begin{array}{c}0.01 * * * \\
(0.000)\end{array}$ & $\begin{array}{c}0.01 * * * \\
(0.000)\end{array}$ & $\begin{array}{c}0.01 * * * \\
(0.000)\end{array}$ & $\begin{array}{l}0.01 * * * \\
(0.001)\end{array}$ \\
\hline Domestic & & $\begin{array}{c}-0.08 \\
(0.377)\end{array}$ & $\begin{array}{l}-0.03 \\
(0.717)\end{array}$ & $\begin{array}{c}-0.07 \\
(0.508)\end{array}$ & $\begin{array}{l}-0.17^{*} \\
(0.082)\end{array}$ \\
\hline Foreign & & reference & reference & reference & reference \\
\hline Single trait & & $\begin{array}{c}-0.15 \\
(0.157)\end{array}$ & $\begin{array}{l}-0.22^{*} \\
(0.053)\end{array}$ & $\begin{array}{c}-0.17 \\
(0.128)\end{array}$ & $\begin{array}{l}-0.19^{*} \\
(0.100)\end{array}$ \\
\hline Multiple trait & & reference & reference & reference & \\
\hline Cotton & & & & & $\begin{array}{c}0.49 * * * \\
(0.001)\end{array}$ \\
\hline Maize & & & & & reference \\
\hline Soy & & & & & $\begin{array}{c}0.13 \\
(0.453)\end{array}$ \\
\hline Potato & & & & & $\begin{array}{l}0.54 * * * \\
(0.000)\end{array}$ \\
\hline Other crops & & & & & $\begin{array}{c}0.09 \\
(0.562)\end{array}$ \\
\hline $\begin{array}{l}\text { Herbicide } \\
\text { tolerance }\end{array}$ & & & $\begin{array}{l}-0.06 \\
(0.725)\end{array}$ & & \\
\hline Insect resistant & & & reference & & \\
\hline Other trait & & & $\begin{array}{c}0.25 \\
(0.160)\end{array}$ & & \\
\hline Food & & & & $\begin{array}{c}-0.11 \\
(0.547)\end{array}$ & \\
\hline Non-food & & & & reference & \\
\hline Constant & $\begin{array}{c}29,218.29^{* * * *} \\
(0.001)\end{array}$ & $\begin{array}{c}35,168.60 * * * \\
(0.000)\end{array}$ & $\begin{array}{c}33,361.16^{* * *} \\
(0.000)\end{array}$ & $\begin{array}{c}33,656.90^{* * *} \\
(0.000)\end{array}$ & $\begin{array}{c}30,755.96^{* * * *} \\
(0.001)\end{array}$ \\
\hline Observations & 58 & 58 & 58 & 58 & 58 \\
\hline R-squared & 0.21 & 0.26 & 0.32 & 0.26 & 0.43 \\
\hline
\end{tabular}

Note: Robust p-values in parentheses. $* * *, * *, *$ indicate statistical significance at the 1,5 , and $10 \%$ levels, respectively. Dependent variable is time taken in days (natural log) for passing through the scientific process. Reference category refers to a non-EU (foreign) based company, submitting a multiple trait and insect resistant GE plant (model 3). 


\section{Applicant}

Applies to APHIS ${ }^{1}$ to conduct field trials; for interstate movement; or importation of a genetically modified organism (GMO).

Application done either via the notification or permit process.

If $\mathrm{GMO}$ is a PIP2, then applicant also applies to the $\mathrm{EPA}^{3}$ for approval.

If the GMO is to be used for food, the applicant also applies to the FDA 4 for approval - a voluntary decision as it is not compulsory.

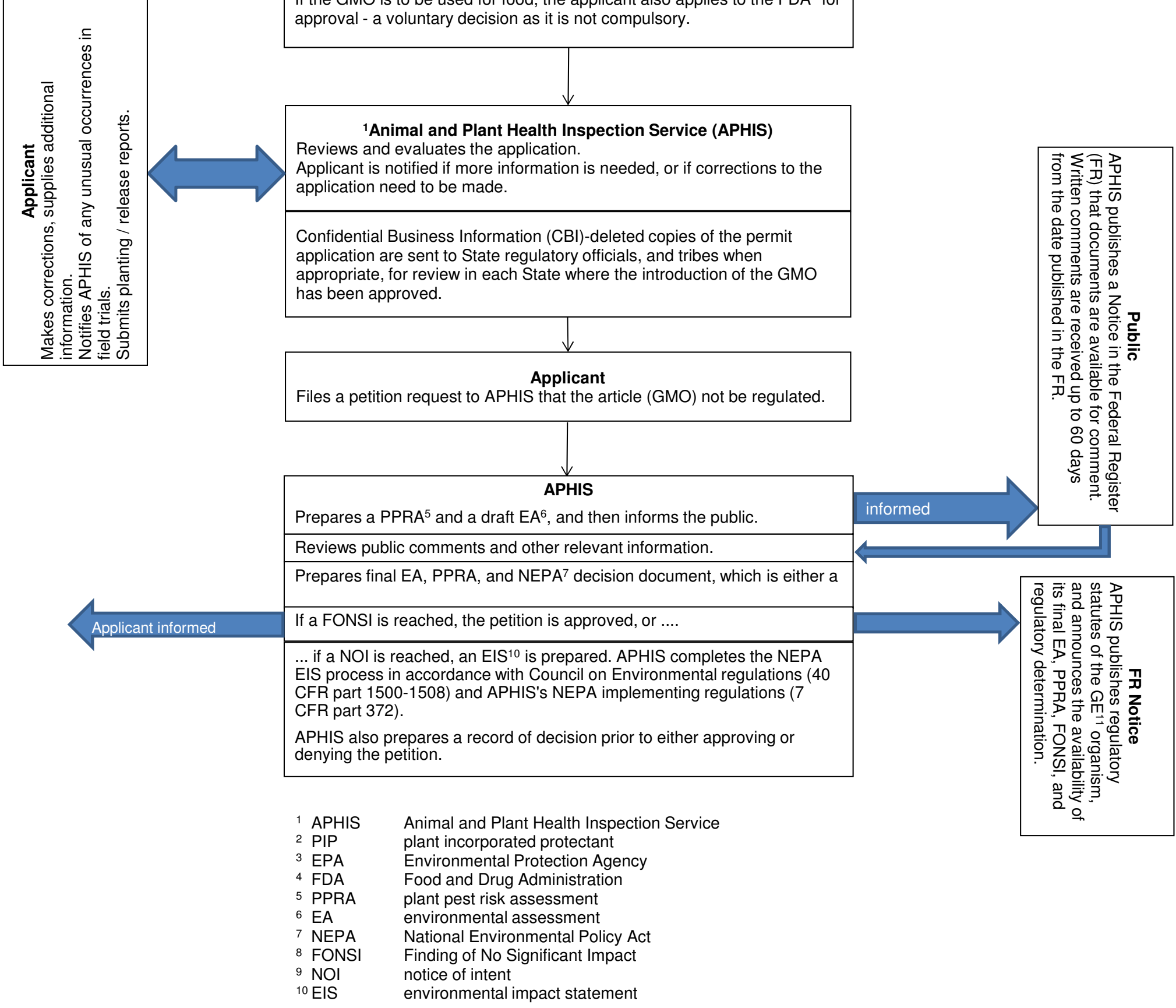

Figure S1. The US's approval process for GE crops pre 6 March 2012 (USDA APHIS, 2012). 


\section{Applicant}

Applies to APHIS 1 to conduct field trials; for interstate movement; or importation of a genetically modified organism (GMO).

Application done via either the notification or permit process.

If $\mathrm{GMO}$ is a PIP2, then applicant also applies to the $\mathrm{EPA}^{3}$ for approval.

If the GMO is to be used for food, the applicant also applies to the FDA ${ }^{4}$ for approval - a voluntary decision as it is not compulsory.

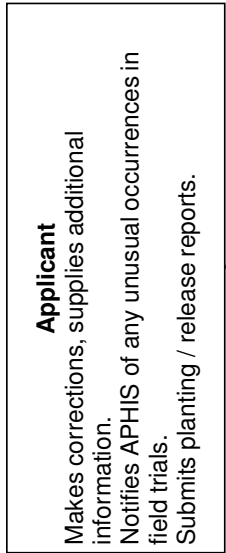

\section{${ }^{1}$ Animal and Plant Health Inspection Service (APHIS)}

Reviews and evaluates the application.

Applicant is notified if more information is needed, or if corrections to the application need to be made.

Confidential Business Information (CBI)-deleted copies of the permit application are sent to State regulatory officials, and tribes when appropriate, for review in each State where the introduction of the GMO has been approved.

\section{Applicant}

Files a petition request to APHIS that the article (GMO) not be regulated.

\section{APHIS}

APHIS determines if the petition is complete and involves the public, and uses this time to identify potential issues and impacts that it can use in its subsequent evaluation of the petition.

Prepares: a PPRA ${ }^{5}$ and an $\mathrm{EA}^{6}$. Level of public participation is determined by whether or not APHIS finds that the petition raises substantive new

Approach 2: Petition raises

Approach 1: Petition raises

\section{substantive new issues.}

APHIS publishes a notice in FR which announces its preliminary determination and the availability of its $\mathrm{EA}, \mathrm{FONSI}^{8}$ and PPRA for a 30 day review period.

After the review period, APHIS reviews and evaluates any information received.

If no substantive information is received to warrant the alteration of: EA, FONSI and PPRA, then the preliminary determination becomes final once the public is informed.

APHIS's preliminary regulatory determination does not become effective, snd it notifies the public of its intent to conduct additional analyses.

Prepares amended EA, a new FONSI and/or a revised PPRA (if necessary).

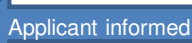

After reviewing and evaluating any new information, APHIS's preliminary regulation becomes final and effective once the public has been notified.

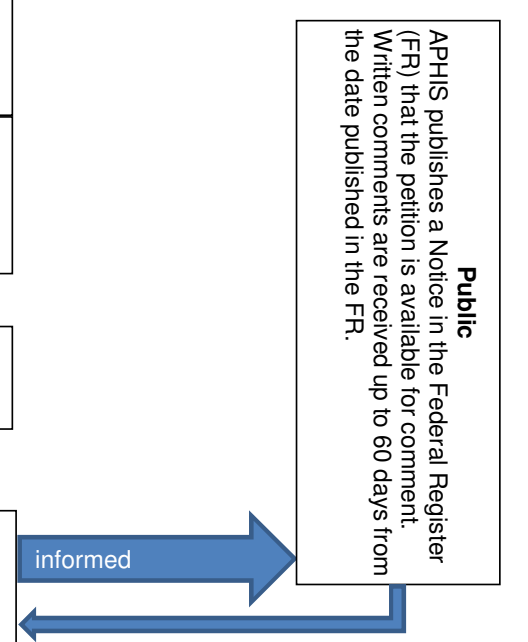

APHIS solicits comments from the public on a draft EA and

After the comment period, APHIS reviews and evaluates the comments and any relevant information so received.

APHIS revises the PPRA and prepares a final EA, the latter is used to prepare a NEPA decision document which is either a

If a FONSI is reached, the petition is denied or approved.

1 APHIS Animal and Plant Health Inspection Service

2 PIP

3 EPA plant incorporated protectan

4 FDA

5 PPRA

6 EA

7 NEPA

8 FONSI

$9 \mathrm{NOI}$

${ }^{10} \mathrm{EIS}$ Environmental Protection Agency Food and Drug Administration plant pest risk assessment environmental assessment National Environmental Policy Act Finding of No Significant Impact notice of intent environmental impact statement 


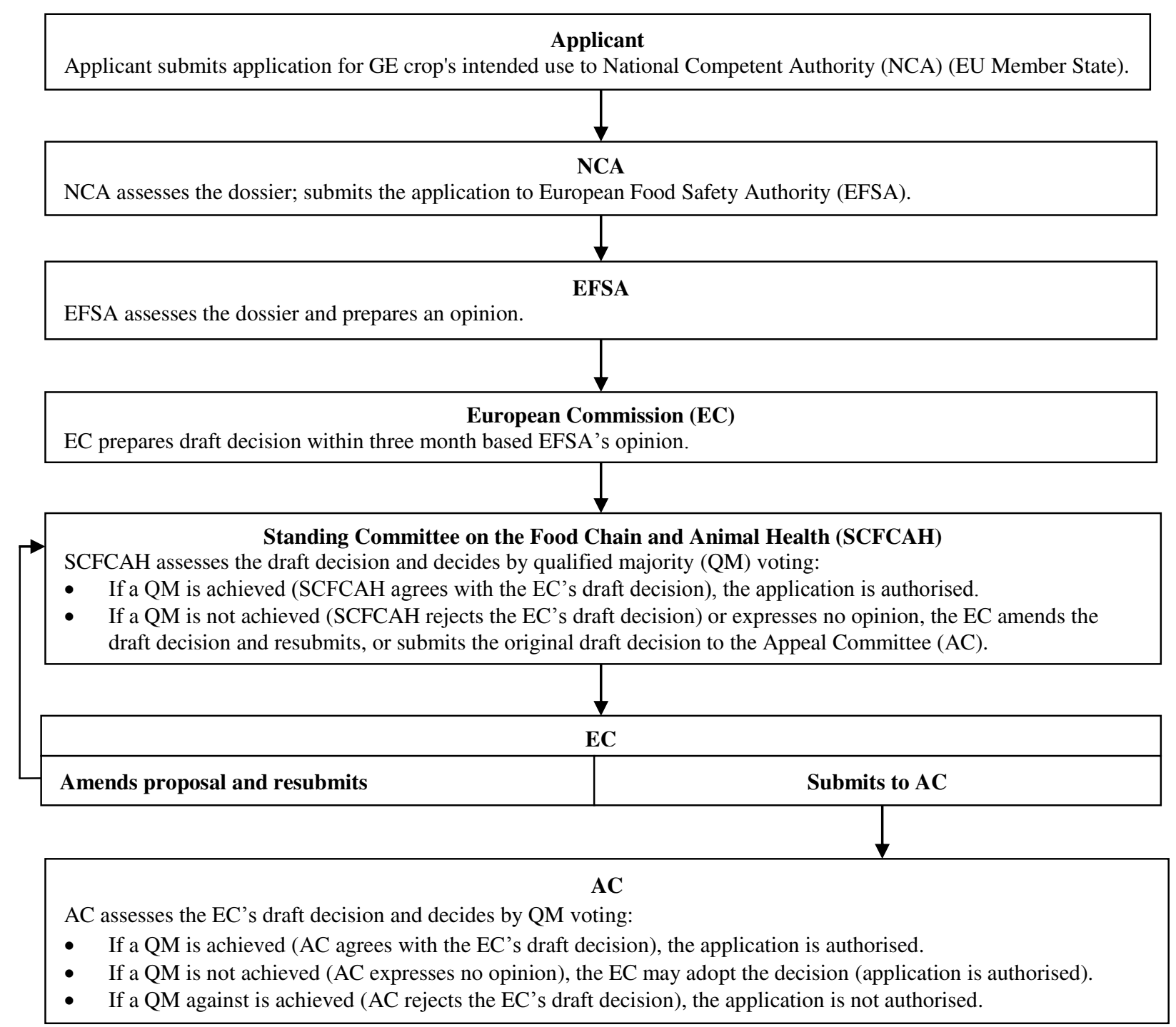

Figure S3. Approval process for GE crops with a favourable EFSA opinion and a positive draft decision by the EC (from Smart et al., 2015). 
(a)

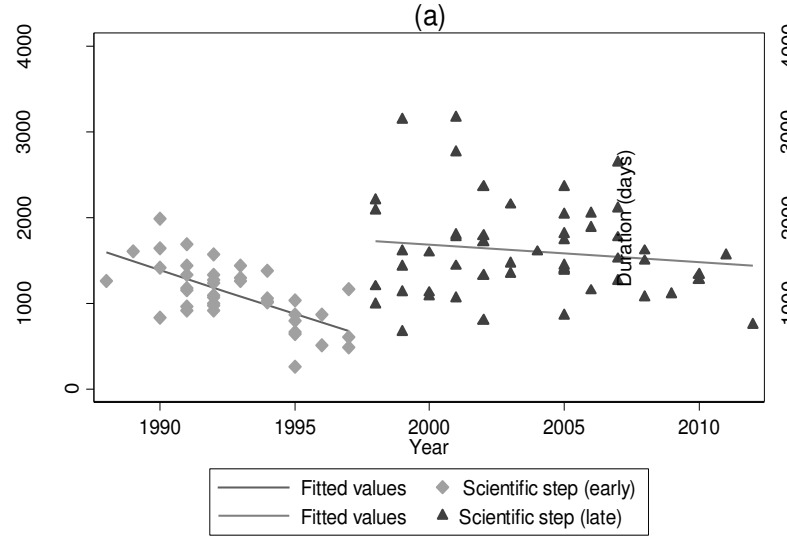

(c)

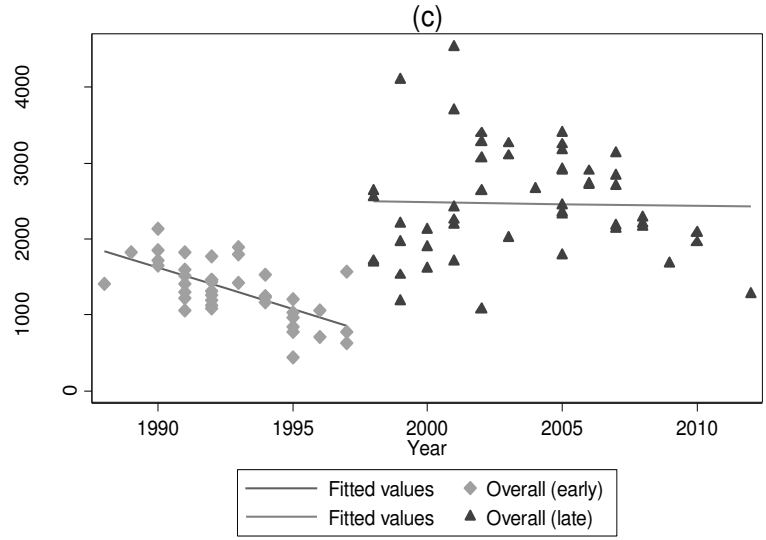

(b)

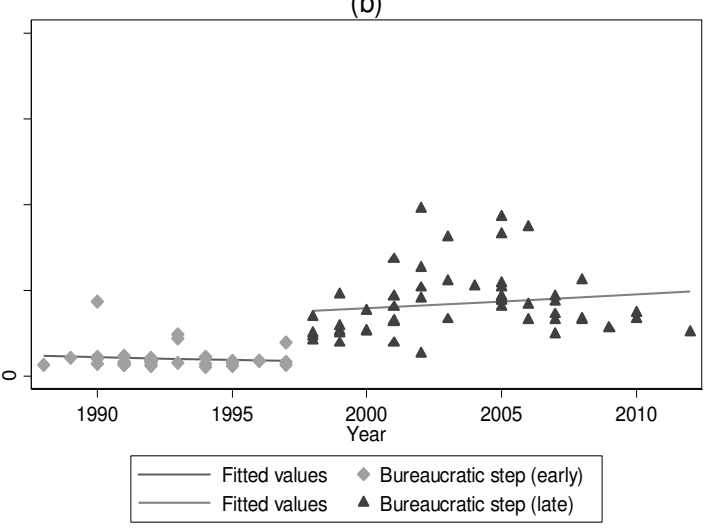

Figure S4. Trends in time (days) taken for the approval, split into the scientific (field trial) (a) and political (bureaucratic) (b) steps, and overall time taken (c), for all GE crops deregulated as well as those awaiting the completion of the 'bureaucratic' process, in the US. 

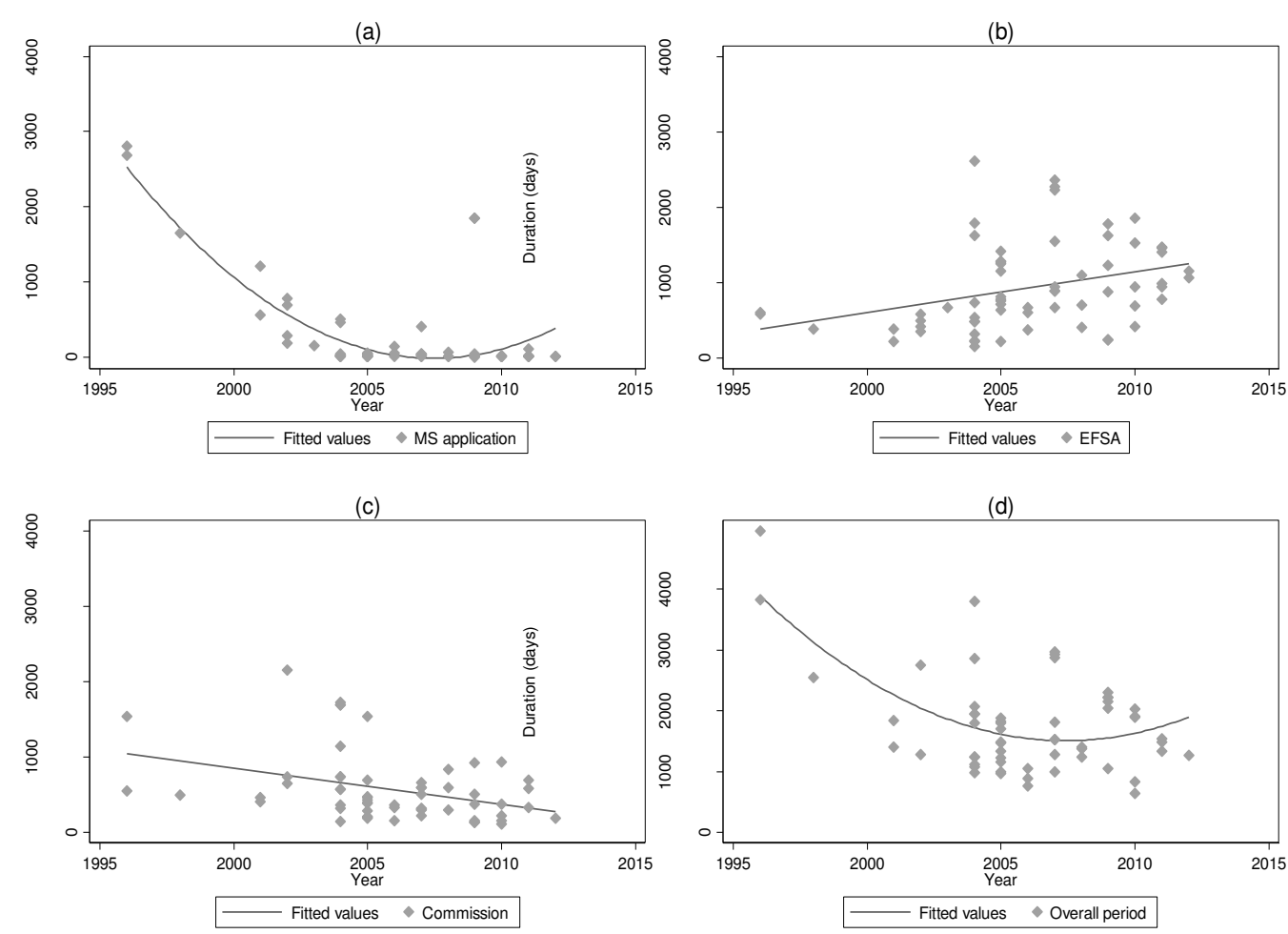

Figure S5. Trends in time (days) taken for the aprroval, split into the Member State application step (a), the 'risk assessment' step (b), the 'political' step at the Commission (c), and overall time taken (d), for all GE crops approved and those awaiting the outcome of the 'political' step in the EU. 